\title{
PERAN SERANGGA AIR BAGI IKAN AIR TAWAR
}

\author{
Asyari* \\ $\because$ Peneliti pada Balai Riset Perikanan Perairan Umum. Marıana-Palembang
}

\begin{abstract}
ABSTRAK
Kebanyakan serangga air pada umumnya hidup di air tawar, hanya sebagian kecil yang hidup di air laut. Di samping itu, menguntungkan sebagai pakan alamı beberapa jenis ikan, serangga aır dapat juga merugikan antara lain sebagai predator bagi larva atau ikan-ikan berukuran kecil, bahkan ada serangga yang dapat menyebabkan penyakit bagi maniusia. Pada umumnya ikan-ikan karnivora dan ikan omnıvora air tawar memanfaatkan serangga air sebagai pakan alami. baik sebagai pakan utama maupun sebagai pakan pelengkap
\end{abstract}

KATA KUNCI: $\quad$ serangga air, pakan alami, predator

\section{PENDAHULUAN}

Serangga (insecta) pada dasarnya adalah kelompok hewan darat yang menghuni hampir setiap jenis habitat, beberapa kelompok antara lain terdapat di air tawar dan sejumlah kecil yang terdapat di air laut (Hoeve, 1996). Serangga merupakan salah satu kelas dari phylum Arthropoda (hewan beruas-ruas). kelas lain adalah Crustacea, Myriapoda, dan Arachnida.

Hal yang menarik dari serangga adalah mempunyai beberapa tahapan dalam daur hidup mereka, yaitu tahap telur, larva, nympha, kepompong. dan dewasa. Sebagian dari serangga semua tahapan kehidupan berada di darat atau udara, tetapi ada juga yang larva (nympha) berada di air (akuatik), sedangkan dewasa hidup di darat atau udara

Beberapa serangga air menggunakan udara engsung sebagai sumber oksigen, misal larva nyamuk mempunyai spirakel terbuka yang langsung berhubungan dengan udara luar pada waktu di permukaan air dan akan menutup waktu menyelam. Kumbang air membawa udara di bawah sayap, dengan demikian dapat tinggal beberapa lama di dalam air. Serangga yang bernafas seperti itu harus naik ke permukaan untuk memperbarui persediaan udara.

Di darat serangga memanfaatkan sayap dengan
baik untuk terbang, mobilitas yang tinggi
memungkinkan menjelajahi kawasan yang luas dan
merupakan suatu cara menghindar dari musuh
(predator) terutama golongan Arachnida (laba-laba).
Serangga air dan serangga darat yang habitat dekat
air mempunyai musuh golongan Arachnida, ikan
karnivora, dan omnivora.

Serangga dapat menguntungkan, namun juga dapat merugikan, yang menguntungkan antara lain mereka dapat menyerbukkan tanaman, sumber makanan bagi ikan. penghasil sutera, dan madu. Yang merugikan yaitu dapat merusak dan menghancurkan tanaman, bahkan dapat menularkan penyakit.

Beberapa ikan ekonomis penting yang bersifat omnivora dan karnivora memanfaatkan serangga air sebagai pakan utama dan pakan pelengkap. David (1963) mengatakan bahwa ikan patin (Pangasius sp.) di alam bebas makanan alami terdiri atas serangga, biji-bijian, ikan, udang-udangan, dan Moluska. Sedangkan ikan belida bersifat karnivora dengan pakan utama ikan, pakan pelengkap udang, dan serangga air (Adjie et al., 1999).

Menurut Utomo \& Asyari (1999), di perairan hutan rawa air tawar serangga air banyak djumpai pada serasah daun dan kayu mati yang terendam dalam air. Ordo yang mendominasi adalah Coleoptera terutama famili Dytiscidae dan Hydrophillidae, ordo Hemiptera famili Nepidae dan Hydrometridae. ordo Odonata famili Cordulidae

Tulisan ini menguraikan beberapa kelompok serangga yang hidup di air tawar dan beberapa jenis ikan yang bersifat karnivora dan omnivora yang memanfaatkan serangga air tersebut sebagai pakan alami.

\section{KLASIFIKASI}

Kategori klasifikasi untuk semua hewan (termasuk insekta) pada dasar adalah phylum, kelas, ordo (bangsa), family (suku,marga), genus (keluarga), dan spesies (jenis). Mengingat begitu banyak famili (suku) dari serangga ini, maka dalam pengklasifikasian ini hanya ditampilkan kelas dan ordo. Famili akan dibahas pada bab berikut, terutama famili-famili dari serangga air dengan beberapa contoh. Lilies (1991) telah mengklasifikasikan serangga sebagai berikut (Tabel 1)

Sub kelas Apterygota (serangga tanpa sayap) dibagi atas 4 ordo; Collembola (ekor pegas), Diplura, Thysanura (ekor bulu), dan Protura. Collembola 
Tabei 1. Klasifikasi serangga berdasarkan pada Lilies (1991)

\begin{tabular}{|c|c|c|}
\hline 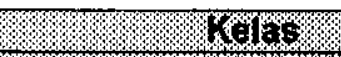 & $\checkmark 1040$ & 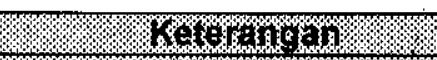 \\
\hline 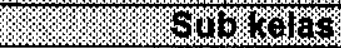 & \%s $1 \% 82$ & 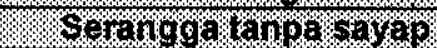 \\
\hline Ordo & Collembola & Ekor pegas \\
\hline Ordo & Diplura & - \\
\hline Ordo & Thysanura & Ekor bulu \\
\hline Ordo & Protura & - \\
\hline Sub kelas & $\begin{array}{l}\text { Pterygota } \\
\text { I. Exopterygota }\end{array}$ & Serangga bersayap \\
\hline Ordo & Ephemeroptera & Lalat sehari \\
\hline Ordo & Odonata & Bangsa capung \\
\hline Ordo & Orthoptera & Jengkerik, belalang \\
\hline Ordo & Isoptera & Bangsa rayap \\
\hline Ordo & Plecoptera & Lalat batu \\
\hline Ordo & Dermaptera & Cocopet \\
\hline Ordo & Embioptera & - \\
\hline Ordo & Mallophaga & Kutu pengunyah \\
\hline Ordo & Anoplura & - \\
\hline Ordo & Thysanoptera & - \\
\hline Ordo & Hemiptera & Kepik, kutu daun \\
\hline Ordo & Homoptera & - \\
\hline Ordo & $\begin{array}{c}\text { Neuroptera } \\
\text { II.Endopterygota }\end{array}$ & Undur-undur \\
\hline Ordo & Coleoptera & Bangsa kumbang \\
\hline Ordo & Mecoptera & Kalajengking \\
\hline Ordo & Tricoptera & Pita-pita \\
\hline Ordo & Lepidoptera & Kupu-kupu, ngengat \\
\hline Ordo & Diptera & Lalat, nyamuk \\
\hline Ordo & Siphonaptera & - \\
\hline Ordo & Hymenoptera & Semut, lebah, tawon \\
\hline
\end{tabular}

hanya mempunyai 6 segmen perut dengan ekor berlipat, di bawah bercabang yang bekerja sebagai pegas yang dapat melontarkan ke udara. Diplura dan Thysanura masing-masing mempunyai 2 atau 3 ekor yang panjang, sedangkan Protura, sebagai serangga yang amat kecil di tanah merupakan satu-satunya serangga yang tidak pernah memiliki antena.

Serangga lain semua termasuk dalam Pterygota (serangga bersayap), dan terbagi pula atas 2 kelompok yaitu Exopterygota dan Endopterygota.

Odonata (bangsa capung) merupakan serangga karnivora, capung dewasa paling sering nampak terbang di sepanjang sungai, danau atau perairan air tawar lain. Serangga ini memiliki 2 pasang sayap yang tidak begitu lebar disertai urat-urat halus. Larva (nympha) penuh hidup di air, dengan labium yang sudah mengalami penyesuaian agar dapat menangkap mangsa (Hoeve, 1996)

Hemiptera adalah serangga yang dapat hidup di permukaan perairan sampai dengan dasar perairan, sebagian bersifat karnivora dan sebagian pemakan detritus. Sebagian besar famili dari ordo ini termasuk serangga air yang sebagian besar waktu dan siklus hidup berada dalam air (Hart \& Fuller, 1974).
Coleoptera adalah jenis serangga yang dapat hidup pada semua tipe habitat, sebagian besar waktu dalam siklus hidup berada dalam perairan, senang hidup pada tumbuhan di rawa, dan telur menempel pada tumbuhan. Coleoptera ada yang bersifat karnivora dan ada juga pemakan detritus (Merritt \& Cummins, 1996)

\section{PERAN DAN KEHIDUPAN SERANGGA AIR}

Kebanyakan dari serangga air pada umumnya hidup di air tawar, hanya sebagian kecil yang hidup di air laut. Fisiologi serangga air berbeda dengan fisiologi serangga darat, serangga air langsung mengambil oksigen dari air dan banyak antara lain yang mempunyai insang berupa kepak-kepak tubuh yang mempunyai kutikula tipis dilengkapi dengan trachea.

Beberapa serangga air yang bersifat predator ada yang dapat mengeluarkan ammonia yang sangat beracun untuk melumpuhkan mangsa mereka terutama hewan air yang berukuran kecil seperti larva udang, ikan, berudu, cacing, dan lain-lain. Sebaliknya, serangga air ini juga berperan sebagai pakan alami ikan-ikan karnivora dan omnivora, bahkan ikan-ikan ini juga memakan serangga darat yang suka beterbangan di antara tumbuhan air. 
Di samping menguntungkan sebagai pakan alami beberapa jenis ikan, serangga air ada pula yang merugikan antara lain sebagai predator bagi larva atau ikan-ikan yang berukuran kecil. Bahkan ada jenis serangga (ordo Diptera) yang dapat menyebabkan penyakit bagi manusia, seperti nyamuk malaria dan nyamuk demam berdarah.

Berikut ini diuraikan beberapa contoh serangga air yang sering dijumpai di berbagai tipe perairan air tawar atau perairan umum.

Lalat sehari (Ephemera danica atau ordo Ephemeroptera) (Gambar 1). Serangga ini suka terbang bergerombolan pada musim panas, bertelur di permukaan air atau pada batu-batuan di dalam air Pada fase nympha hidup sepenuh dalam air (akuatik), sedangkan dewasa sering dijumpai di tepi sungai, kolam, danau, dan aliran air lain. Suka menyelam berulang-ulang dalam air sehingga sering dimakan ikan, nympha, dan dewasa sebagai makanan penting ikan di perairan.

Kinjeng atau capung jarum (Calopterix sp. atau famili Coenagriodae). Abdomen panjang dan ramping, pangkal sayap berbentuk seperti batang. Saat dewasa berwarna hijau kekuningan dan hitam, yang jantan berwarna lebih indah. Pada fase nympha hidup di air, dewasa sering dijumpai di sepanjang aliran sungai dan rawa, nympha dapat memanjat batang tumbuhan air untuk mencari mangsa, sedangkan dewasa pada umumnya terbang di bawah tajuk tumbuhan

Capung mata besar (Aeshna cyanea atau famil Aeshnidae). Sering ditemukan di sekitar sungai dan rawa, dikenal sebagai penerbang yang kuat, pada umumnya berwarna coklat tua dan sering berwarna kebiru-biruan atau kehijauan pada dada, dewasa dapat mencapai $7,5 \mathrm{~cm}$. Pada fase nympha bersifat akuatik, nympha, dan dewasa bersifat predator.

Kumbang penyelam (Dytiscus marginalis atau famili Dytiscidae) (Gambar 2). Kumbang ini termasuk predator. Larva dan dewasa hidup dalam air, dan makan berbagai binatang air termasuk ikan-ikan kecil. Sedangkan kepompong muncul di tanah yang lembab sekitar perairan. Sering mengambil udara di permukaan air, saat menyelam memakai gelembung udara yang ada di bawah kelopak sayap. Kumbang dewasa dapat berukuran $3 \mathrm{~cm}$, berwarna hitam, coklat, atau kekuning-kuningan.

Kumbang air (famili Hydrophilidae). Serangga ini bersifat herbivora, terdapat di perairan yang tenang seperti danau dan kolam. Telur diletakkan dalam kantung-kantung pada tanaman air, larva hidup di air. selanjutnya meninggalkan air untuk menjadi pupa dalam lubang di bawah tanah. Serangga dewasa memakan bangkai, sedangkan larva memakan binatang air yang kecil-kecil.

Kumbang gasing (famili Gyrinidae). Sering terlihat berenang di permukaan air yang tenang seperti di danau, waduk, atau kolam. Saat dewasa sebagai pemakan bangkai terutama makan serangga yang jatuh di permukaan air, larva makan berbagai binatang air yang berukuran kecil, sering juga bersifat kanibal.

Anggang-anggang (famili Gerridae). Serangga ini sering terlihat berkelompok di permukaan air yang tenang yang banyak terlindung tanaman di pinggir perairan, kadang-kadang dapat juga ditemukan di air mengalir. Bertubuh panjang dan langsing dengan kaki tengah dan belakang saling berdekatan terpisah dari

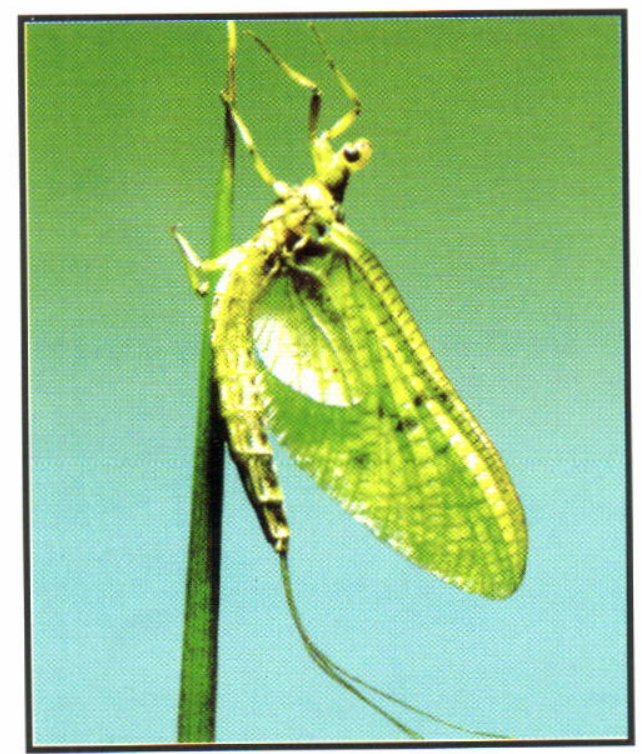

Gambar 1. Lalat sehari (Ephemera danica) dewasa, sering dimakan ikan karnivora Sumber/Sources: Hoeve (1996) 


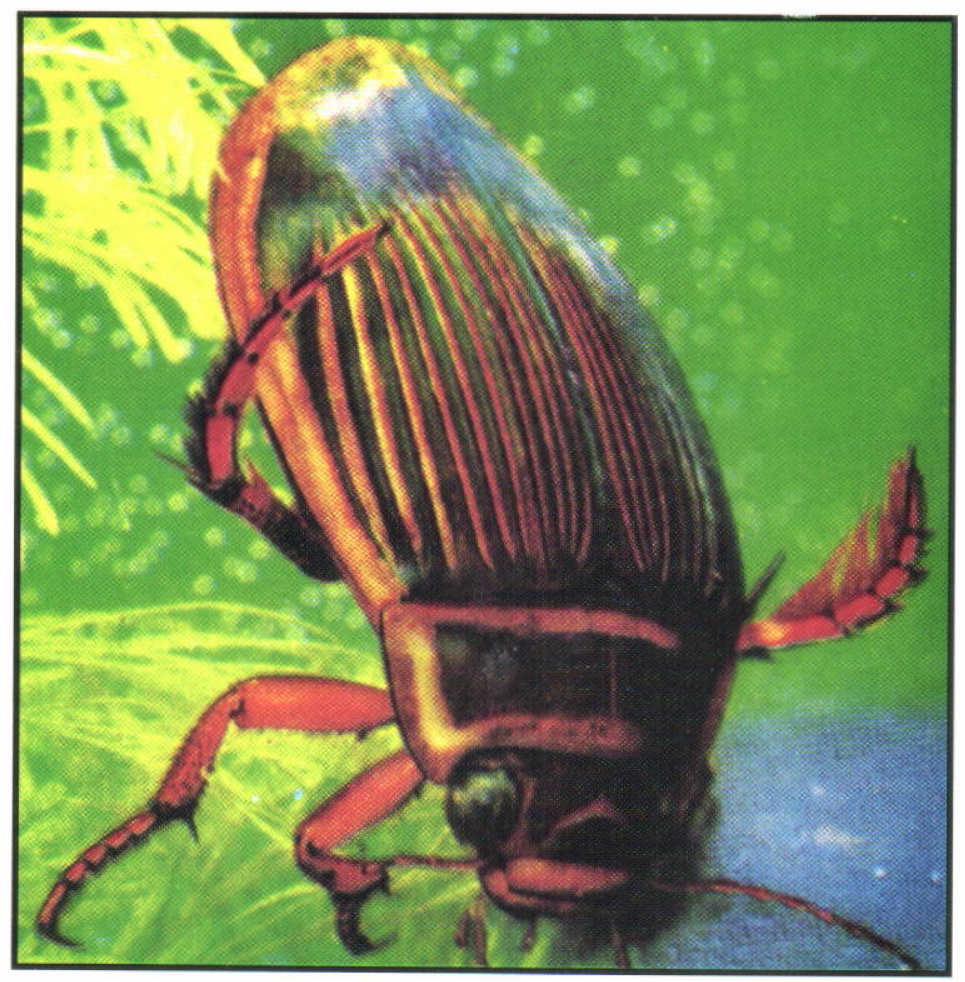

Gambar 2. Kumbang penyelam (Dytiscus marginalis) tergolong hewan karnivora Sumber/Sources: Hoeve (1996)

kaki depan. Induk meletakkan telur dalam batang tanaman yang terletak di bawah permukaan air. Pada umumnya memakan hewan-hewan (serangga) kecil yang jatuh di air.

Uir-uir (Notonecta glauca atau famili Notonectidae). Bersifat predator terhadap serangga lain termasuk ikan-ikan kecil. Serangga ini disebut juga kepik perenang punggung karena suka berenang dengan posisi terbalik dengan punggungnya berada di bawah, dapat berenang dengan cepat menggunakan kaki belakang sebagai dayung

Kepik air (Corixa punctata atau famili Corixidae) Lebih kecil dari Notonecta. Sering dijumpai di kolam danau atau aliran air lain, dapat berenang cepat dengan gerakan tak menentu, sering menggantung atau berpegangan pada tanaman di perairan. Bersifat predator, makan larva, dan binatang air yang kecilkecil termasuk ikan. Induk meletakkan telur pada tanaman air.

Kepik air raksasa (Belostoma indicum atau famili Belostomitidae). Berbentuk bulat telur dengan panjang mencapai $5 \mathrm{~cm}$, ditemukan di danau maupun kolam, tungkai belakang kuat, dan pipih digunakan untuk berenang, tungkai depan digunakan untuk menangkap mangsa berupa hewan-hewan air seperti berudu, dan ikan-ikan kecil (Lilies, 1991).
Nyamuk (Aedes aegypty atau famili Culicidae). Serangga yang merugikan manusia karena bersifat pengisap darah dan dapat menularkan penyakit demam berdarah. Pada saat larva dan pupa bersifat akuatik, dapat dijumpai di kolam, selokan dan wadahwadah yang berisi air atau air yang tergenang. Saat larva memakan bahan-bahan organik atau bersifat predator memakan larva nyamuk lain (Lilies, 1991).

Nyamuk biasa (Culex pipiens atau famili Culicidae). Serangga betina suka mengisap darah hewan maupun darah manusia, sedangkan yang jantan hanya makan cairan buah atau tumbuhtumbuhan. Larva dapat ditemukan dalam hampir segala genangan air seperti rawa, tambak, kolam, selokan, dan lain-lain, larva yang disebut jentik-jentik suka memakan detritus atau kotoran yang membusuk dalam air, selain itu juga memakan jasad-jasad renik yang terdapat dalam air (Lilies, 1991).

\section{SERANGGA AIR SEBAGAI PAKAN ALAMI IKAN}

Jenis-jenis pakan alami ikan sangat beragam sesuai dengan tabiat makan, jenis, dan tingkat umur. Ada ikan yang bersifat herbivora yaitu ikan yang pakan alami berasal dari tumbuh-tumbuhan, omnivora yang memakan tumbuh-tumbuhan maupun hewan, dan karnivora yaitu ikan yang pakan alami berasal dari hewan, baik hewan invertebrata maupun hewan vertebrata 


\section{Ikan Karnivora}

Ikan air tawar yang bersifat karnivora pada umumnya memakan serangga air baik sebagai pakan utama maupun sebagai pakan pelengkap. Hasil penelitian Arifin \& Utomo (1987); Utomo et al. (1990); Utomo \& Asyari (1999) menunjukkan bahwa, ikanikan seperti lais bangah (Kryptopterus micronema) termasuk ikan karnivora yang cenderung memakan hewan invertebrata terutama jenis serangga air sebagai pakan alami, begitu juga jenis ikan-ikan lain seperti putak, keli, lais bamban, dan lais tapah (Tabel 2).

Selanjutnya, Muchsin et al. (2003) mengatakan bahwa ikan sidat pada tingkat larva (elver) telah memberikan indikasi sebagai ikan karnivora dengan memakan bermacam-macam jenis serangga air seperti ordo Diptera, Coleoptera, Trichoptera, dan Hemiptera (Tabel 3).

Salah satu jenis ikan karnivora yang unik adalah ikan sumpit (Toxotes sp.), dalam mencari mangsa ikan ini mampu menembak jatuh serangga-serangga dengan sumburan butir-butir air (Gambar 3). Ikan sumpit kecil hanya mampu menyemprotkan butiran air sejauh beberapa inci, tetapi yang dewasa dapat menembak seekor serangga yang jauh mencapai 90 $\mathrm{cm}$. Ikan sumpit juga makan makanan lain kalau tidak ada serangga, tetapi kebiasaan menembak tetap ada.

Tabel 2.

Persentase (\%) serangga air di dalam usus ikan karnivora

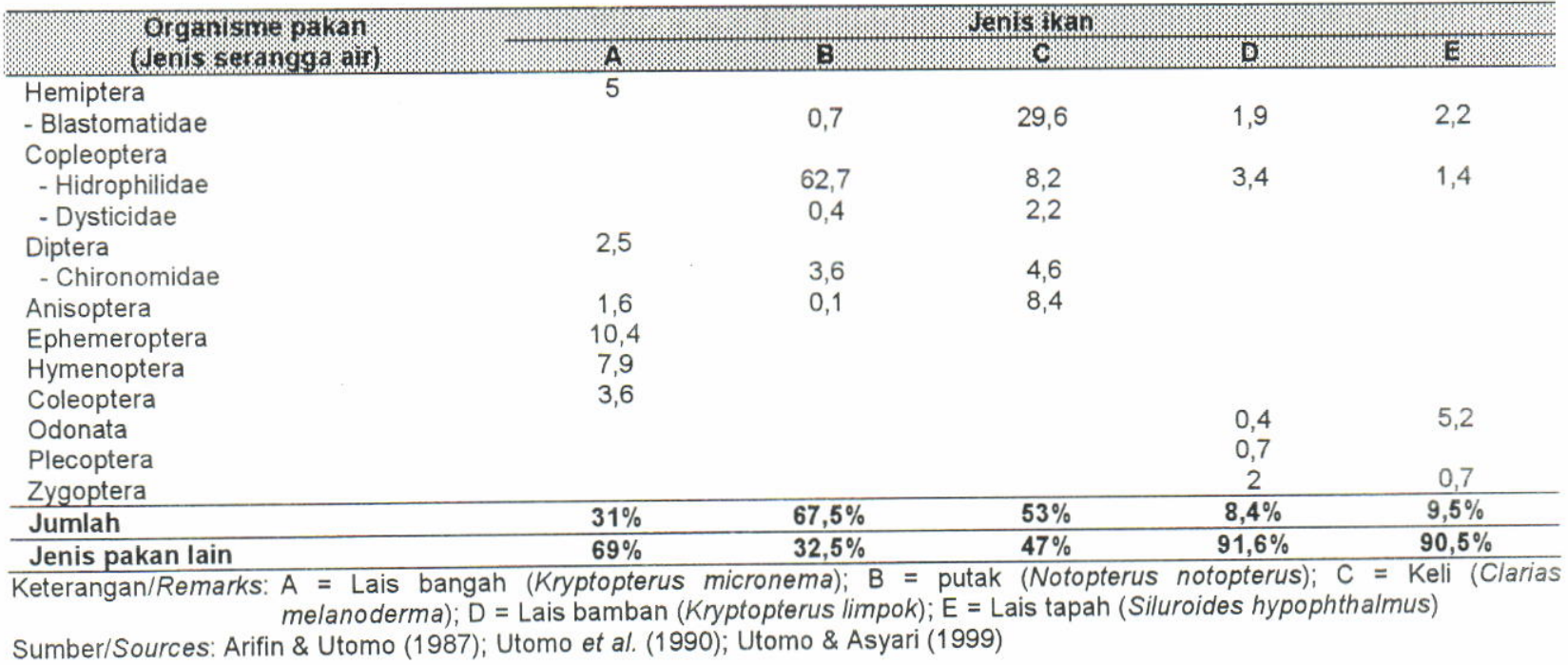

Tabel 3. Persentase (\%) serangga air dalam usus ikan juvenile sidat (Anguilla sp.)

\begin{tabular}{|c|c|c|}
\hline \multirow{2}{*}{$\begin{array}{l}\text { Organisme pakan } \\
\text { Uens serangga ail }\end{array}$} & \multicolumn{2}{|c|}{ Stasiun pengamatan } \\
\hline & Kawua & Watua wa \\
\hline \multicolumn{3}{|l|}{ Diptera } \\
\hline - Tipulidae & 16,15 & 7,46 \\
\hline - Tabanidae & 13,08 & - \\
\hline - Ceratopogonidae & 4,62 & - \\
\hline - Culicidae & 4,23 & - \\
\hline - Tendipedidae & 1,54 & 6,13 \\
\hline - Dixidae & 1,53 & \\
\hline \multicolumn{3}{|l|}{ Coleoptera } \\
\hline - Haliplidae & 1,54 & 3,07 \\
\hline - Dytiscidae & 1,54 & - \\
\hline - Hyrophilidae & - & 4,39 \\
\hline \multicolumn{3}{|l|}{ Trichoptera } \\
\hline - Hydroptilidae & 3,08 & \\
\hline \multicolumn{3}{|l|}{ Hemiptera } \\
\hline - Naucoridae & 1,54 & 7,90 \\
\hline Tidak teridentifikasi & 51,15 & 71,05 \\
\hline Jumlah & 100 & 100 \\
\hline
\end{tabular}

Sumber/Sources: Muchsin et al (2003) 


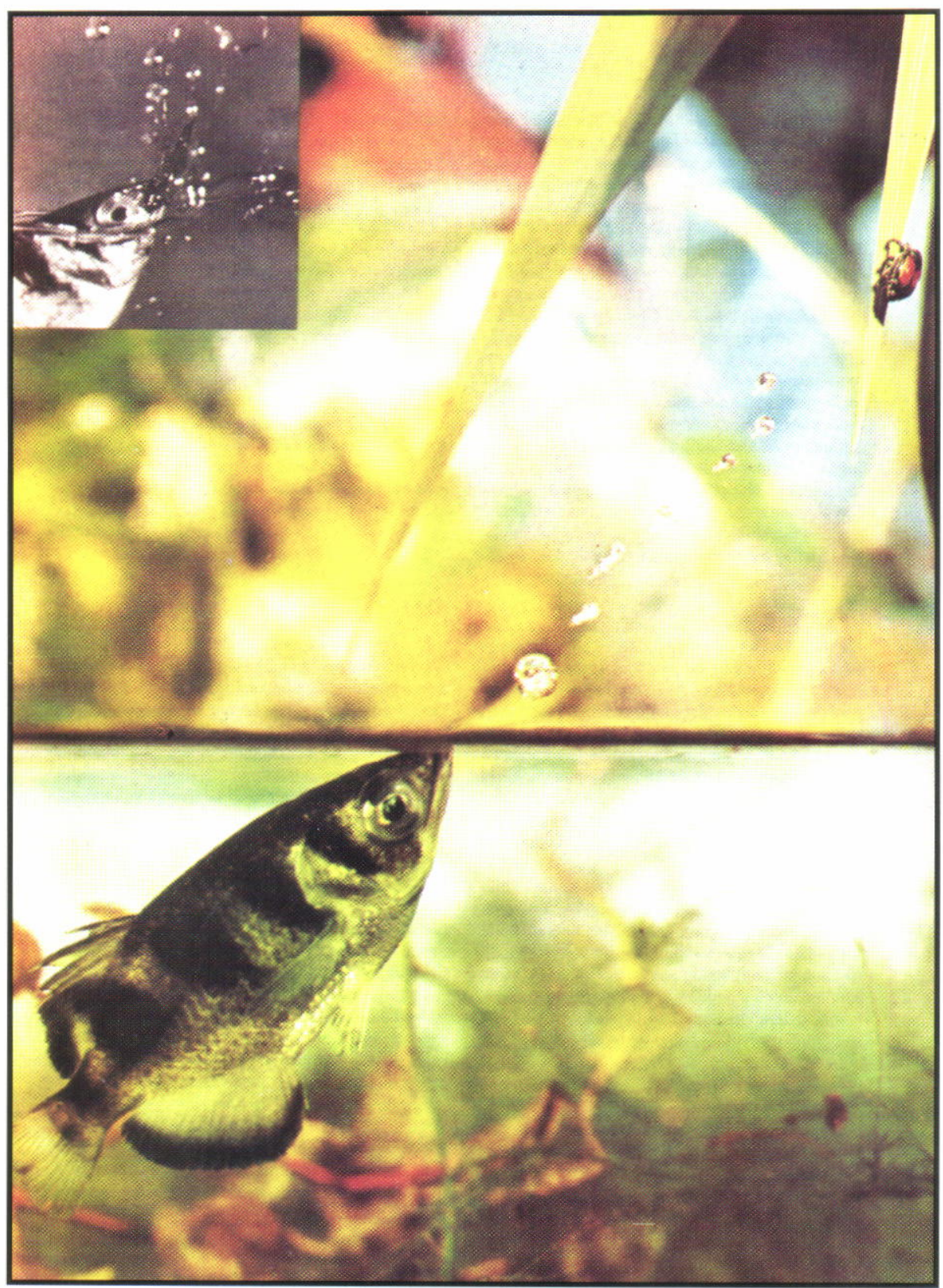
Gambar 3. Ikan sumpit (Toxotes sp.) dapat menembak seekor serangga air sejauh $90 \mathrm{~cm}$.
Sumber/Sources: Hoeve (1996)

\section{Ikan Omnivora}

Beberapa jenis ikan omnivora sering memanfaatkan serangga air sebagai pakan alami. Menurut Utomo \& Asyari (1999), ikan patik (Mystus nemurus) dan ikan lelandin (Mystus nigriceps) adalah ikan omnivora yang cenderung karnivora, serangga yang sering ditemukan dalam usus adalah Hymenoptera, Anisoptera, Ephemeroptera, dan Diptera (Tabel 4). Hasil penelitian lain seperti ikan botia (Botia macracanthus) termasuk hewan omnivora yang cenderung karnivora, berdasarkan pada analisis pola kebiasaan pakan alami pada ikan botia, 105 ekor dengan metode frekuensi kejadian ternyata $40 \%$ ikan memakan serangga air (Samuel et al., 1995). Begitu juga dikatakan oleh Tjahjo (1991), ikan genggehek atau kepiat (Mystacoleucus marginatus) termasuk ikan omnivora dengan pakan utama potongan tumbuhan dan pakan pelengkap serangga air. Selanjutnya, menurut Gaffar et al. (1991), pakan alami ikan semah (Labeobarbus douronensis) dengan metode frekuensi kejadian menunjukkan bahwa $32,8 \%$ dari ikan yang diamati merupakan pemakan serangga air. 
Tabel 4. Persentase (\%) serangga air di dalam usus ikan omnivora

\begin{tabular}{|c|c|c|}
\hline \multirow{2}{*}{ 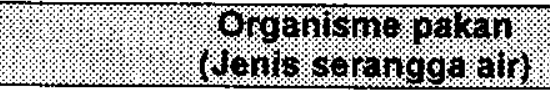 } & \multicolumn{2}{|c|}{ 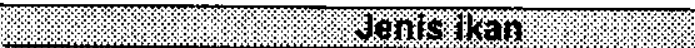 } \\
\hline & 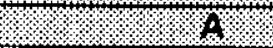 & 3 \\
\hline Anisoptera & 2,3 & - \\
\hline Ephemeroptera & 7,1 & - \\
\hline Hymenoptera & 4,5 & 41 \\
\hline Diptera & - & 2 \\
\hline Jumlah & $13,9 \%$ & $43 \%$ \\
\hline Jenis pakan lain & $86,1 \%$ & $\mathbf{5 7 \%}$ \\
\hline
\end{tabular}

Keterangan /Remarks: $\mathrm{A}=$ Ikan patik (Mystus nemurus); $\mathrm{B}=$ Lelandin (Mystus nigriceps)

Sumber/Sources: Utomo \& Asyari (1999)

\section{IKAN SEBAGAI PEMBERANTAS SERANGGA}

Perairan rawa yang luas atau genangan air seperti kolam, tambak bahkan selokan-selokan kecil dapat merupakan tempat penetasan bagi beberapa jenis serangga air penyebab penyakit, seperti penyakit malaria, demam berdarah, dan lain-lain. Dengan melakukan pemberantasan lebih dini secara biologis, terhadap larva atau jentik nyamuk pada tempattempat penetasan tersebut diharapkan akan dapat mengurangi penyebaran penyakit-penyakit itu. Cara bıologis yang dapat dilakukan adalah dengan menebar jenis Ikan pemakan larva serangga terutama pada tempat-tempat yang dimaksud

Jenis-jenis ikan yang menyukai larva serangga sebagai pakan alaminya antara lain lkan cupang (Betta splenden). Menurut Satyani (2003) jenis-jenıs pakan hidup yang amat disuka oleh ikan cupang adalah Tubifek, Daphnia, Moina, dan larva atau jentik nyamuk

Ikan gupi (Lebistes sp.). Ikan ini dapat mencapai panjang $6 \mathrm{~cm}$, suka mencari makan pada permukaan air, terutama larva nyamuk, yang setelah dewasa dapat menyebarkan bermacam jenis penyakit.

Ikan nyamuk (Gambusia sp.). Ikan yang berasal dari Amerika utara dan mirip ikan gupi, suka berenang di bawah permukaan air sambil memakan larva nyamuk atau hewan kecil lain. Ikan ini mampu memakan nyamuk sebobot tubuh sendiri dalam sehari, maka ikan ini sangat penting dimasukkan di negara-negara yang banyak nyamuk malaria dan nyamuk demam berdarah seperti Indonesia.

\section{KESIMPULAN}

Serangga pada prinsip merupakan hewan darat, namun beberapa antara lain hidup di air, terutama di lingkungan air tawar. Serangga dapat menguntungkan dan merugikan manusia, mereka dapat menyerbukkan tanaman, merusak dan menghancurkan tanaman, bahkan dapat menyebabkan beberapa penyakit. Selain itu, produk serangga seperti sutera dan madu sangat berharga bagi manusia. Serangga air juga dapat berperan sebagai pakan alami ikan-ikan karnivora dan omnivora, selanjutnya secara tidak langsung juga ikut menguntungkan manusia.

\section{DAFTAR PUSTAKA}

Adjie, S., Husnah, \& A. K.Gaffar. 1999. Studi biologi ikan belida (Notopterus chitala) di daerah aliran Sungai Batanghari, Propinsi Jambi. Jurnal Penelitian Perikanan Indonesia. Vol.V.No. 1. Pusat Penelitian dan Pengembangan Perikanan. Badan Penelitian dan Pengembangan Pertanian

Arifin, Z. \& Utomo A. D. 1987. Pakan alami ikan putak (Notopterus totopterus) di lubuk lampam, Sumatera Selatan. Buletin Penelitian Perikanan Darat. Vol.6.No.1. Balai Penelitian Perikanan Air Tawar. Bogor.

David, A. 1963. Fishery biology of schilbeid catfish (Pangasius pangasius). Indian Journal of Fisheries. P 522-599.

Gaffar, A. K. A. D.utomo, \& S. Adjie. 1991. Pola pertumbuhan, makanan, dan fekunditas ikan semah (Labeobarbus douronensis) di Sungai Komering bagian hulu. Sumatera Selatan. Buletin Penelitian Perikanan Darat. Vol.10.No.1. Balai Penelitian Perikanan Air Tawar. Bogor

Hart, C. W. \& Fuller L. H. 1974. Pollution ecology of Freshwater Invertebrates. Academic Press. New York. San Fransisco. London. 313-371

Hoeve, W. V. 1996. Ensiklopedi Indonesia seri fauna ikan. PT. Ichtiar Baru Van Hoeve.

Hoeve, W. V. 1996. Ensklopedi Indonesia seri fauna serangga. PT. Ichtiar Baru Van Hoeve

Lilies. S. C 1991. Kunci determinasi serangga. Penerbit Kanisıus (Anggota IKAPI). Yokyakarta.

Merrit, R. W. \& Cummins K. W. 1996. An Introduction to the aquatic insect of North America. 
Muchsin, I., Zairion, \& Samliok Ndobe. 2003 Beberapa aspek biologi larva sidat (Anguilla sp.) di muara Sungai Poso, Sulawesi Tengah. Prosiding Sumber Daya Perikanan Sidat Tropik. UPT Baruna Jaya. BPPT.

Samuel, D. Prasetyo, \& Akrimi. 1995. Distribusi dan beberapa aspek biologi ikan botia (Botia macracanthus) di daerah aliran Sungai Batanghari Jambi. Prosiding Seminar Hasil Penelitian Perikanan Air Tawar 1993 atau 1994. Balai Penelitian Perikanan Air Tawar. Badan Penelitian dan Pengembangan Pertanian.

Satyani, D. 2003. Pengaruh umur induk ikan cupang (Betta splenden Regan) dan jenis pakan terhadap fekunditas dan produksi larvanya. Jurnal Penelitian perikanan Indonesia. Edisi Akuakultur. Vol.9. No.4. Badan Riset Kelautan dan Perikanan. Departemen Kelautan dan Perikanan. Jakarta
Tjahjo, H. D. W 1991. Kebiasaan pakan komunitas ikan di Waduk Jatiluhur. Buletin Penelitian Perikanan Darat. Vol.10.No.2. Balai Penelitian Perikanan Air Tawar. Bogor.

Utomo, A. D., Adjie S., \& Asyari. 1990. Aspek biologi ikan lais di perairan lubuk lampam Sumatera Selatan. Buletin Penelitian Perikanan Darat. Vol.9.No.2. Balai Penelitian Perikanan Air Tawar. Bogor.

Utomo, A. D. \& Asyari. 1999. Peranan ekosistem hutan rawa air tawar bagi kelestarian sumber daya perikanan di Sungai Kapuas, Kalimantan Barat. Jurnal Penelitian Perikanan Indonesia. Vol.V.No.3. Pusat Penelitian dan Pengembangan Perikanan. Badan Penelitian dan Pengembangan Pertanian. Jakarta. 